\title{
ESTIMATING THE ELEMENTAL BIOMASS COMPOSITION OF DESMODESMUS SP. CULTIVATED IN SUGARCANE STILLAGE
}

Marija B. Tasić ${ }^{\star}$, Luisa Fernanda Rios Pinto², Daniel Santos Fernandes ${ }^{2}$, Gabriela Filipini Ferreira², Rubens Maciel Filho ${ }^{2}$

(ORIGINAL SCIENTIFIC PAPER) UDC 664.111:582.263.1:662.756.3

\author{
${ }^{1}$ Faculty of Technology, University of Niš, Leskovac, Serbia \\ ${ }^{2}$ Department of Process and Product Development (DDPP), Faculty of Chemical Engineering (FEQ), University of Campinas \\ (UNICAMP), São Paulo, Brazil
}

Cultivating algae on various stillage types present an alternative to current stillage application for fertirrigation of the sugarcane. The objective of this study was to determine how algal concentration, nutrient removal efficiency and elemental composition of Desmodesmus sp. algae change in response to different (raw and digested) types of stillage. Algal biomass was cultivated and harvested at laboratory scale. Obtained concentrations were $0.5 \mathrm{~g} / \mathrm{L}$ and $0.3 \mathrm{~g} / \mathrm{L}$ for Desmodesmus sp. grown in raw and digested stillage, respectively. At these concentrations, total carbon (TC) and total nitrogen (TN as Total Kjeldahl Nitrogen or N-TKN) removal from stillage medium accounted $39.78 \%$ and $5.58 \%$ for raw; $20.83 \%$ and $5.43 \%$ for digested stillage, respectively. The Desmodesmus sp. used in the present study contained high carbon and oxygen content, similar to other algal species. Calcium, phosphorus, and sulfur were the three most abundant inorganic elements. Both biomasses were free of chlorine and with the low content of potassium. The phosphorous content in both biomasses was in the range of $6.03 \%-6.84 \%$, which could classify these biomasses as useful plant nutrients.
Keywords: Sugarcane stillage, Desmodesmus sp., biomass, elemental composition.

\section{Introduction}

Sugarcane stillage, also known as vinasse, is a biorefinery by-product. It is obtained from the bottom of the distillation column from $1 \mathrm{G}$ (first generation) and $2 \mathrm{G}$ (second generation) technologies at relative rates of 6-15 L stillage/L bioethanol [1-3]. While $1 \mathrm{G}$ sugarcane stillage disposal is regulated by law due to its toxic environmental impact, $2 \mathrm{G}$ sugarcane stillage is used for fertirrigation of the sugarcane field [2]. Fertirrigation, as a simple and inexpensive approach, was reported to have a negative environmental impact which can be more harmful especially concerning high dinitrogen monoxide $\left(\mathrm{N}_{2} \mathrm{O}\right)$ emissions [4]. Additionally, local communities are facing the problem of a strong unpleasant odor of the stillage. Anaerobic digestion of the stillage can generate a better environmental impact producing a surplus of bioenergy, such as biomethane. However, this comes with an unchanged odor and still relatively high nutrients concentrations in an anaerobic digestion effluent. Cultivating algae on raw or digested stillage intends to show that negative environmental impact and odor of the stillage nutrients can almost be eliminated. It is because algae assimilate nutrients from the stillage for its growth and synthesize cell components.

Currently, the algae used in the cultivation of the stillage medium are: Chlorella vulgaris [5-7], Chlorella sp. Bejerinck [8],
Chlorella sorokiniana [9], Chlamydomonas reinhardii [10], Tetraselmis suecica [8], Scenedemsus sp. [11] and Neochloris oleoabundans [12]. The influence of nutrients on the algae growth in raw or digested stillage is mostly studied $[5,6,8,9,11,12]$. However, the influence of chemical oxygen demand (COD) concentration on the algal growth is controversial. For example, Marques et al. [5] show that Chlorella vulgaris is not able to grow in a medium of raw stillage with the COD content higher than 4\%. Ozturk and Demir [8] showed that a higher content of raw sugarcane stillage (5 and 10\%) decreased the cell number, chlorophyll $\mathrm{Chl}$ a, Chl b, Chl a/b ratio, carotenoid contents, the biomass yield and the protein content of both Chlorella sp. and Tetraselmis suecica. Similar results [10] are reported for Chlamydomonas reinhardii cultivated in $1 \%-5 \%$ raw stillage media. Solovchenko et al. [9] reported a high biomass concentration with $20 \mathrm{~g} / \mathrm{L}$ of COD in stillage at the start of semi-batch Chlorella sorokiniana cultivation, while higher raw stillage contents up to $40 \%$ added to Guillard modified medium contributed positively to Scenedesmus sp. biomass production at a light intensity of 10000 lux [11]. Furthermore, even though digested samples have a significant presence of volatile fatty acids (VFA) which serve as an organic source of carbon [13], the production may need the add-

\footnotetext{
*Author address: Marija B. Tasić, Faculty of Technology, University of Niš,

Bulevar oslobodjenja 124, 16000 Leskovac, Serbia

E-mails: marijat14@yahoo.com, mtasic@tf.ni.ac.rs

The manuscript received: September, 26, 2016.

Paper accepted: October, 24, 2016.
} 
on C-source in the form of $\mathrm{NaHCO}_{3}[12]$ or $\mathrm{CO}_{2}$ [5]. This phenomenon was not reported for raw stillage samples. The N/P of about 5:1, suggesting N-limitation [14], is the excellent ratio for algae to grow and induce the accumulation of lipids. As it can be seen in Table 1, both raw and diluted stillages show a wide range of N/P ratio and need dilution instead of N, P sources add-in. Dilution can limit the photosynthetic carbon flux which is necessary for the lipid accumulation [15]. However, dilution is also required not only to avoid an excess of N, P sources but also to di- minish turbidity, reduce the toxicity of some compounds, the limit of photo-oxidative damage and solve the problem of the harvest water management. Since the stillage already has a negative environmental impact, and its dilution could increase the demands of limited clean and fresh water supplies, the use of the stillage for the algae growth must be maintained as undiluted. Only de Mattos and Bastos [16] showed that heterotrophic cultivation of Desmodesmus sp. in the undiluted stillage was promising.

Table 1. Sugarcane stillage chemical composition

\begin{tabular}{|c|c|c|c|c|c|c|c|c|c|c|c|c|}
\hline \multirow[t]{2}{*}{ Parameters, $\mathrm{mg} / \mathrm{L}$} & \multirow{2}{*}{$\begin{array}{l}\text { [12] } \\
\text { Raw }\end{array}$} & \multirow[t]{2}{*}{ [17] } & \multicolumn{3}{|l|}{ [18] } & \multirow[t]{2}{*}{ [8] } & \multirow[t]{2}{*}{ [11] } & \multirow[t]{2}{*}{ [9] } & \multirow{2}{*}{\multicolumn{2}{|c|}{$\begin{array}{l}\text { [5] } \\
\text { Digested }\end{array}$}} & \multirow[t]{2}{*}[17]{} & \multirow[t]{2}{*}{ [5] } \\
\hline & & & & & & & & & & & & \\
\hline pH & 4 & 4 & $4-4.5^{a}$ & $3.5-4.5^{b}$ & $3.5-4^{c}$ & & 4 & 3-4 & $3.5 \pm 0.1$ & 8.1 & 6.9 & $6.7 \pm 0.1$ \\
\hline COD & 124900 & 29000 & $37000-57000 \mathrm{a}, \mathrm{d}$ & $19000-45000^{\mathrm{b}, \mathrm{d}}$ & $15000-35000^{c, d}$ & & & 20000 & $23.2 \pm 1.16$ & 7944 & 9000 & $0.3 \pm 0.01$ \\
\hline Total N & 2876.5 & 550 & $750-790$ a,e & $330-480^{b, e}$ & $260-350^{c, e}$ & 4022 & $245.51^{\mathrm{e}}$ & & & 579.6 & 600 & \\
\hline Ammonia & 752 & 40 & & & & & & & $0.01 \pm 0.01$ & 473.3 & 220 & $0.02 \pm 0.01$ \\
\hline $\mathrm{NO}_{3}$ & & & & & & & & $15 \pm 1.3$ & $0.03 \pm 0.01$ & & & 0.01 \\
\hline Total $\mathbf{P}$ & $102^{f}$ & & $100-350$ a,g & $90-610^{b, g}$ & $90-500^{c, g}$ & & 24.5 & $773 \pm 73^{f}$ & $0.05^{f}$ & $98.6^{f}$ & 32 & $0.01^{f}$ \\
\hline $\mathrm{SO}_{4}$ & 11360 & 450 & $1500^{a}$ & $1600^{b}$ & $2030^{c}$ & & & $178 \pm 18$ & & 1331.3 & 32 & \\
\hline (VFA) & 1511.6 & & & & & & & & & 697.1 & & \\
\hline
\end{tabular}

The knowledge of the elemental biomass composition is shown to be of great importance for various calculations in industry. Very often, due to lack of published data, an average and simplified elemental biomass composition of yeast $\left(\mathrm{CH}_{1.8} \mathrm{O}_{0.5} \mathrm{~N}_{0.2}\right)$ is taken into account to calculate elemental balances of various microbial processes. However, the biomass composition varies depending on the type of microorganism [19], growth conditions [20], harvesting conditions and isolation methods [21]. Thus, the elemental biomass composition should be determined for each particular microorganism. However, to the best author's knowledge only Torri et al., [22] reported that elemental composition in (\%, by weight) of Desmodesmus sp. is: carbon (51.96), oxygen (33.87), hydrogen (7.31) and nitrogen (6.86). It is important to note that the elemental composition of microbial biomass has to be improved to contain not only organic but also inorganic elements due to more accuracy in calculations of basic thermodynamic properties (i.e., biomass stoichiometric formula, enthalpy, entropy and density).

The aim of this article is to determine the elemental composition of Desmodesmus sp. biomass cultivated in sugarcane stillage. Also, the influence of the growth conditions on the elemental biomass composition is discussed. For that purpose, Desmodesmus sp. grown in both raw and digested sugarcane stillage was analyzed for their elemental content.

\section{Materials and methods}

\section{Stillage}

Raw and digested stillage samples were collected from the sugarcane processing industry Usina São Martinho in the city of Pradópolis, São Paulo, Brazil and frozen in the laboratory until use.

\section{TC and TN analysis}

The measurements of TC and TN in the stillage samples before inoculation and after cultivation were carried out on a carbon analyzer TOC-VCSN (Shimatzu, Kyoto, Japan). Stillage and spent stillage samples were centrifuged and diluted prior analysis.

\section{Microorganisms and growth conditions}

The culture bank of green microalgae Desmodesmus sp., donated by the Laboratório de Pesquisas com Organismos Aquáticos (LAPOA), Grupo Integrado de Aquicultura e Estudos Ambientais (GIA), Universidade Federal do Paraná (UFPR), Curitiba/Paraná, was maintained in sterilized BG-11 media [23]. Desmodesmus sp. inoculum was grown autotrophically in $250 \mathrm{~mL}$ Erlenmeyer flask filled with $200 \mathrm{~mL}$ (total volume) of cultivating sterilized BG-11 media and $10 \%$ of the culture bank inoculum. The experiments were carried out in duplicate under following conditions: $\mathrm{pH} 7.0$; the light flux of $62 \mu \mathrm{E}$ $\mathrm{m}^{-2} \mathrm{~s}^{-1}$ for $24 \mathrm{~h}$; shaking rate of $250 \mathrm{rpm}$; temperature of $26 \pm 4{ }^{\circ} \mathrm{C}$; period of 9 days (the end of the exponential growth phase). These cultivated cells were used to inoculate stillage. Heterotrophic cultivation of Desmodesmus $\mathrm{sp}$. was carried out in duplicate in $250 \mathrm{~mL}$ Erlenmeyer flasks with $200 \mathrm{~mL}$ (total volume) of stillage and $20 \%$ of the autotrophic inoculum at $\mathrm{pH} 7.0,25^{\circ} \mathrm{C}, 250 \mathrm{rpm}$ for 11 days. 
Desmodesmus sp. counting and contamination monitoring

Algal growth was monitored by direct counting of algal cells with a microscope using a Neubauer chamber. Average of the counted values was performed and multiplied by the dilution factor and 50 for the cells per $\mathrm{mL}$ concentration. After cultivation, the broth was centrifuged to obtain a residue and spent stillage. The residue (algal biomass) was dried to constant mass at $105^{\circ} \mathrm{C}$. The algae weight was used to calculate the concentration of the final biomass $(\mathrm{g} / \mathrm{L})$. TC and TN were determined in the spent stillage. The bacterial and fungal contamination was monitored by counting bacterial and fungal colonyforming units in Luria Bertani and Sabouraud dextrose agars, respectively, applying the Pour plate technique.

\section{Elemental analysis}

The samples of Desmodesmus sp. dry biomass were analyzed in triplicate by $\mathrm{CHN}$ analyzer (Perkin Elmer Corp., USA). Mass contents of carbon, hydrogen, and nitrogen are expressed as mass fractions of the dry sample. The contents of inorganic elements in Desmodesmus sp. dry biomass were analyzed by Central Analítica at the Institute of Chemistry (University of Campinas, São Paulo, Brazil) by the scanning electron microscopy with an energy dispersive X-ray analytical system (SEMEDX).

\section{Results and discussion}

During the algal growth, cells absorb nutrients not only to grow but also to synthesize metabolic products such as carbohydrates, proteins, and lipids. The reduction of the presence of nutrients in the culture media, especially nitrogen, stresses the Desmodesmus sp., reducing the chlorophyll content and cell growth. Also, the photosynthesis metabolism turns the synthesis of protein to carbohydrate and lipid [24,25]. Table 2 presents the composition of raw and digested stillage before and after the growth of Desmodesmus sp. As it can be seen in Table 2, stressing conditions (low TC and TN content) in digested stillage caused less carbon and nitrogen utilization of $20.83 \%$ and $5.43 \%$, respectively. As a result of this lower nutrients utilization, the concentrations of Desmodesmus sp. biomass in digested stillage $(0.3 \mathrm{~g} / \mathrm{L})$ was lower compared to the raw one $(0.5 \mathrm{~g} / \mathrm{L})$.

Table 2. The change of the composition in stillage before and after Desmodesmus sp. cultivation

\begin{tabular}{lrrrr}
\hline mg/L & \multicolumn{2}{c}{ Before cultivation } & \multicolumn{2}{c}{ After cultivation } \\
& Raw stillage & Digested stillage & Raw stillage & Digested stillage \\
\hline TC & 14767.05 & 8854.58 & 8892.05 & 7010.00 \\
TN & 4347.16 & 856.17 & 4104.55 & 809.70 \\
\hline
\end{tabular}

In order to achieve a more accurate elemental biomass composition, Desmodesmus sp. cultures must be pure. Biomasses obtained after 11 cultivation days in both raw and digested stillage were without a report of bacterial and fungi contamination. The SEM-EDX analyses carried out on the raw and digested biomass samples were compared with each other, by the appearance in the SEM micrograph. Table 3 and Figure 1 present the results of the SEM-EDX semi-quantitative analyses performed on the major biomass forming elements. Differences among the samples from the two types of biomass mostly reflect the differences in the composition of calcium. Other algal biomass species have relatively high carbon and oxygen content (Table 3 ). The Desmodesmus sp. used in the present study also contained high carbon and oxygen content, $80 \%-83 \%$ and $15 \%-18 \%$, respectively. Nitrogen and hydrogen contents, determined by $\mathrm{CHN}$ analyzer, were $6.03 \%$ and $8.62 \%$ for raw and $6.47 \%$ and $11.01 \%$ for digested stillage, respectively. Those values were similar to that reported of Chlorella vulgaris of $6.2 \%-7.7 \%$ and $7.0 \%-10.0 \%$ for nitrogen and hydrogen, respectively.

Table 3. The SEM-EDX elemental analysis of the Desmodesmus sp. biomass

\begin{tabular}{|c|c|c|c|c|}
\hline \multirow[t]{2}{*}{ Element } & \multicolumn{4}{|c|}{$\%$ by weight } \\
\hline & $\begin{array}{l}\text { Raw } \\
\text { stillage }\end{array}$ & $\begin{array}{l}\text { Digested } \\
\text { stillage }\end{array}$ & $\begin{array}{l}\text { Nannochloropsis } \\
\text { salina [21] }\end{array}$ & $\begin{array}{l}\text { Chlorella } \\
\text { vulgaris } \\
\text { [26] }\end{array}$ \\
\hline Carbon (C) & 80.14 & 83.07 & 70.43 & $51.4-72.6$ \\
\hline Oxygen (0) & 17.68 & 15.48 & 22.19 & $11.6-28.5$ \\
\hline Sodium (Na) & & 0.07 & 0.74 & \\
\hline Magnesium (Mg) & 0.10 & 0.11 & 1.16 & $0.36-0.80$ \\
\hline Phosphorous (P) & 0.09 & 0.29 & 2.42 & $1.0-2.0$ \\
\hline Chlorine (Cl) & & & 0.36 & \\
\hline Potassium (K) & 0.09 & & 1.32 & $0.85-1.62$ \\
\hline Calcium (Ca) & 1.67 & 0.68 & 0.94 & $0.005-0.08$ \\
\hline Sulfur (S) & 0.25 & 0.26 & 0.34 & $0.28-0.39$ \\
\hline Aluminium (Al) & 0.15 & & & \\
\hline Silicium (Si) & 0.18 & & & \\
\hline Iron (Fe) & & 0.14 & & $0.04-0.55$ \\
\hline
\end{tabular}

The algal biomasses tend to be rich in a relatively similar composition of inorganic elements, i.e. calcium, potassium, silicon, phosphorus and magnesium (Table 3 , Figure 1). In analyzing the composition of the two Desmodesmus sp. biomass samples, it appears that calcium, phosphorus and sulfur were the three most abundant inorganic elements. Although variations are significant, phosphorus is one of the most important indices for evaluating the agricultural value of biomass. The phosphorous content of the biomasses used in the present study was in the range of $6.03 \%-6.84 \%$. These phosphorous contents are higher than previously reported for various agricultural wastes of $2.2 \%-2.7 \%$ [27] which could classify these biomasses as useful plant nutrients. 
Low $(0.09 \%)$ or no potassium contents in raw and digested biomasses samples, respectively would also be very positive if biomasses were implemented as fuels plant. Both raw and digested biomasses were free of chlorine, but have a high content of sulfur $(0.25 \%)$. However, chlorine and sulfur are considered to have an increased risk of corrosion.
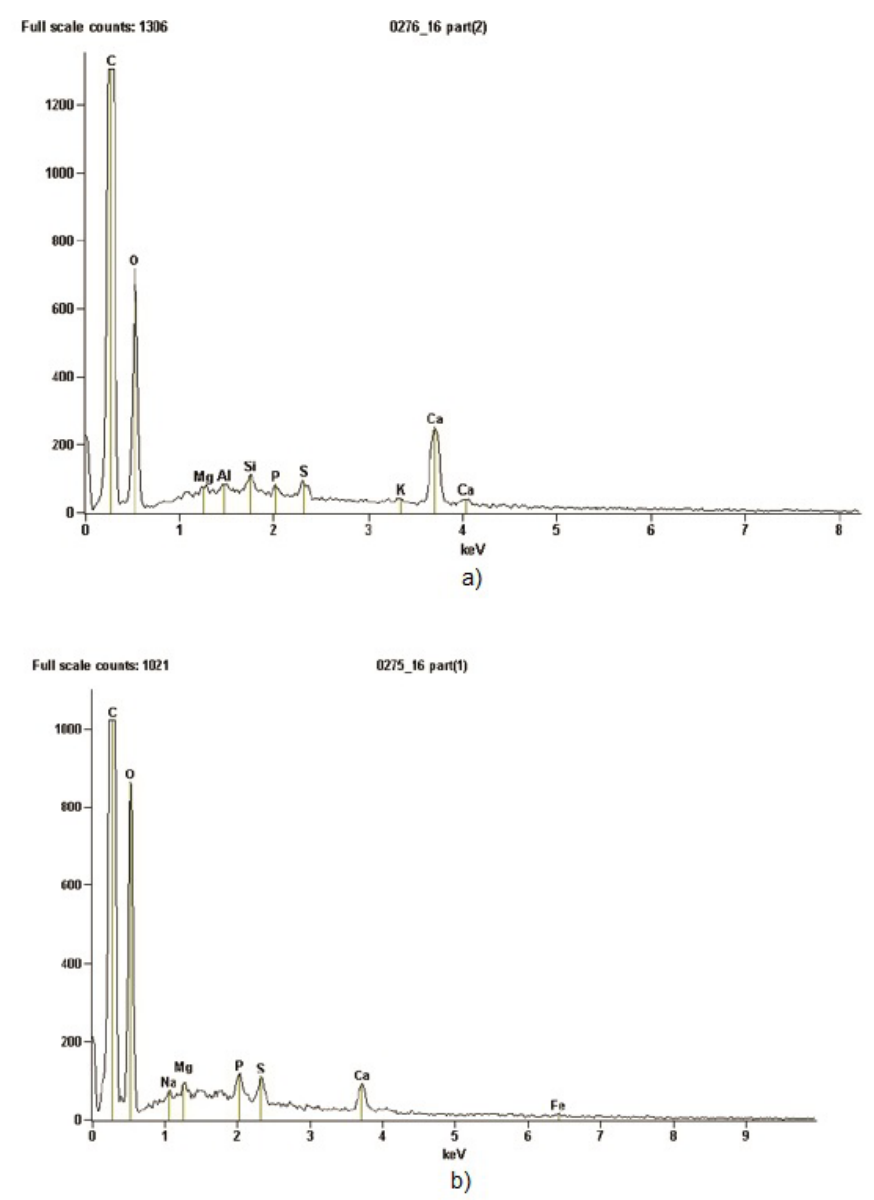

Figure 1. Randomly selected SEM-EDX spectars of Desmodesmus sp. biomass cultivated in: a) raw and b) digested stillage

\section{Conclusions}

Green algae Desmodesmus sp. can be grown in undiluted sugarcane stillage without adding additional sources of nutrients. The TC and TN removal in digested stillage were less than from raw stillage leading to lower digested biomass concentrations. Despite a lower biomass concentration obtained in digested stillage, this medium has been proven as better due to higher carbon, nitrogen and hydrogen contents. However, as discussed earlier, performing a wider elemental analysis of biomass is necessary for more precise calculations of the elemental, enthalpy balances and medium optimization. The SEM-EDX analysis quickly detects and localizes all essential elements in algal biomass from stillage samples. The CHN coupled with SEM-EDX analyses of the samples revealed that there was a substantial increase in carbon and a decrease in the oxygen content in digested biomass caused by stressed cultivating conditions. The biomass cultivated in raw stillage showed a higher calcium content comparing to the biomass from digested stillage and other microalgae species. On the other hand, both biomasses contained low amounts of phosphorus, magnesium, and potassium. Sulfur contents were found to be comparable, while the content of iron in a digested biomass was relatively high.

\section{Acknowledgments}

This study was supported by Fundação de Amparo à Pesquisa do Estado de São Paulo (Processes No. 2014/18979-6; 2014/10064-9 and 2015/26266-2). Authors are thankful to Prof. Telma Teixeira Franco (LEBBPOR - Laboratório de Engenharia Bioquímica, Biorrefino Produtos de Origem Renovável, FEQ, UNICAMP, São Paulo, Brazil) for laboratory equipment used to perform TC and TN analysis.

\section{References}

[1] M. O. de Souza Dias, R. Maciel Filho, P. E. Mantelatto, O. Cavalett, C. E. Vaz Rossell, A. Bonomi, M. R. L. V. Leal, Sugarcane processing for ethanol and sugar in Brazil, Environmental Development, 15 (2015) 35 - 51.

[2] O. Cavalett, T. L. Junqueira, M. O. de Souza Dias, C. Jesus, P. E. Mantelatto, M. P. Cunha, H. C. J. Franco, T. F. Cardoso, R. Maciel Filho, C. E. V. Rossell, A. Bonomi, Environmental and economic assessment of sugarcane first generation biorefineries in Brazil, Clean Technologies and Environmental Policy, 14(3), (2012) 399-410.

[3] M. E. Souza, G. Fuzaro, A. R. Polegato, Thermophilic anaerobic digestion of vinasse in pilot plant UASB reactor, Water Science and Technology, 25(7) (1992) 213-222.

[4] B. S. Moraes, T. L. Junqueira, L. G. Pavanello, O. Cavalett, P. E. Mantelatto, A. Bonomi, M. Zaiat, Anaerobic digestion of vinasse from sugarcane biorefineries in Brazil from energy, environmental, and economic perspectives: Profit or expense?, Applied Energy, 113 (2014) 825-835.

[5] S. S. Marques, I. A. Nascimento, P. F. de Almeida, F. A. Chinalia, Growth of Chlorella vulgaris on sugarcane vinasse: the effect of anaerobic digestion pretreatment, Applied biochemistry and biotechnology, 171(8), (2013) 1933-1943.

[6] L. Travieso, F. Benítez, E. Sánchez, R. Borja, M. León, F. Raposo, B. Rincón, Assessment of a microalgae pond for post-treatment of the effluent from an anaerobic fixed bed reactor treating distillery wastewater, Environmental technology, 29(9) (2008) 985-992.

[7] L. Travieso, F. Benitez, R. Dupeyrón, Algae Growth Potential Measurement in Distillery Wastes, Bulletin of Environmental Contamination and Toxicology, 62(4) (1999) 483-489.

[8] L. Ozturk, Y. Demir, The effects of vinasse on some growth parameters of algae, Fresenius Environmental Bulletin, 10(10) (2001) 766-771.

[9] Solovchenko, S. Pogosyan, O. Chivkunova, I. Selyakh, L. Semenova, E. Voronova, P. Scherbakov, I. Konyukhov, K. Chekanov, M. Kirpichnikov, E. Lobakova, Phycoremediation of alcohol distillery wastewater with a novel Chlorella sorokiniana strain cultivated in a photobioreactor monitored on-line via chlorophyll 
fluorescence, Algal Research, 6(Part B) (2014) 234-241.

[10] Kadioğlu, Ö.F. Algur, Tests of media with vinasse for Chlamydomonas reinhardii for possible reduction in vinasse pollution, Bioresource Technology, 42(1) (1992) 1-5.

[11] N. N. V.Ramirez, M. Farenzena, J. O. Trierweiler, Growth of microalgae Scenedesmus sp. in ethanol vinasse. Brazilian Archives of Biology and Technology, 57(5) (2014) 630-635.

[12] E. Olguin, E. Dorantes, O. S. C. Baltazar, V. J. HernándezLanda, Anaerobic digestates from vinasse promote growth and lipid enrichment in Neochloris oleoabundans cultures, Journal of Applied Phycology, 27(5) (2015) 1813-1822.

[13] E. J. Olguín, Dual purpose microalgae-bacteria-based systems that treat wastewater and produce biodiesel and chemical products within a biorefinery, Biotechnology advances, 30(5) (2012) 1031-1046.

[14] K. Larsdotter, Wastewater treatment with microalgae - a literature review, Vatten, 62 (2006) 31-38.

[15] Y. Li, M. Horsman, B. Wang, N. Wu, C. Q. Lan, Effects of nitrogen sources on cell growth and lipid accumulation of green alga Neochloris oleoabundans, Applied Microbiology and Biotechnology, 81 (2008) 629-636.

[16] L. F. A. de Mattos, R. G. Bastos, COD and nitrogen removal from sugarcane vinasse by heterotrophic green algae Desmodesmus sp., Desalination and Water Treatment, 57(20) (2016) 1-9.

[17] K. Cenciani, M. do Carmo Bittencourt-Oliveira, B. J. Feigl, C. C. Cerri, Sustainable production of biodiesel by microalgae and its application in agriculture, African journal of microbiology research, 5 (2011) 4638-4645.

[18] J. O. B. Carioca, J. J. Hiluy Filho, M. R. L. V. Leal, F. S. Macambira, The hard choice for alternative biofuels to diesel in Brazil, Biotechnology advances, 27(6) (2009) 1043-1050.

[19] J. L. Cordier, B. Butsch, B. Birou, U. von Stockar, The relationship between elemental composition and heat of combustion of microbial biomass, Applied Microbiology and Biotechnology, 25 (1987) 305-312.

[20] Larsson, U. von Stockar, I. W. Marisson, L. Gustafsson, Growth and metabolism of Saccharomyces cerevisiae in chemostat cultures under carbon-, nitrogen-, or carbon and nitrogen-limiting conditions, Journal of Bacteriology, 175(15) (1993) 4809-4816.

[21] P. D. Patil, H. Reddy, T. Muppaneni, A. Mannarswamy, T. Schuab, F. Omar Holguin, P. Lammers, N. Nirmalakhandan, P. Cooke, S. Deng, Power dissipation in microwaveenhanced in situ transesterification of algal biomass to biodiesel, Green Chemistry, 14 (2012) 809-818.

[22] Torri, L. Garcia Alba, C. Samorì, D. Fabbri, D. W. F. (Wim) Brilman, Hydrothermal treatment (HTT) of microalgae: detailed molecular characterization of HTT oil in view of HTT mechanism elucidation, Energy Fuels, 26 (2012) 658-671.

[23] R. Rippka, J. Deruelles, J. B. Waterbury, M. Herdman, R. Y. Stanier, Generic assignments, strain histories and properties of pure cultures of cyanobacteria, Journal of General Microbiology, 111 (1979) 1-61.

[24] P. J. Syrett, in Physiology and biochemistry of algae, R. A. Lewin Ed., Academic Press, New York 1962, 171-188.

[25] L. F. Rios, B. C. Klein, L. F. Luz Jr, R. Maciel Filho, M. R. Wolf Maciel, Nitrogen starvation for lipid accumulation in the microalga species Desmodesmus sp., Applied Biochemistry and Biotechnology, 175(1) (2015) 469-476.

[26] R. K. Mandalam, B. $\varnothing$. Palsson, Elemental balancing of biomass and medium composition enhances growth capacity in high-density Chlorella vulgaris cultures, Biotechnology and Bioengineering, 59(5) (1998) 605-611.

[27] F. S. Zhang, S. Yamasaki, M. Nanzyo, Waste ashes for use in agricultural production: I. Liming effect, contents of plant nutrients and chemical characteristics of some metals, Science of the Total Environment, 284 (2002) 215-225.

\section{Izvod}

\section{PROCENA ELEMENTARNOG SASTAVA BIOMASE DESMODESMUS SP. KULTIVISANE U DŽIBRI ŠEĆERNE TRSKE}

Marija B. Tasić ${ }^{1}$, Luisa Fernanda Rios Pinto ${ }^{2}$, Daniel Santos Fernandes ${ }^{2}$, Gabriela Filipini Ferreira², Rubens Maciel Filho

(ORIGINALNI NAUČNI RAD)

UDK 664.111:582.263.1:662.7564.3

${ }^{1}$ Tehnološki fakultet, Univerzitet u Nišu, Leskovac, Srbija

2Odsek za razvoj procesa i proizvoda, Fakultet Hemijskog inženjerstava, Univerzitet u Kampinasu, Sao Paolo, Brazil

Kultivacija algi na različitim vrstama džibre predstavlja alternativu njenoj trenutnoj primeni za đubrenje šećerne trske. Cilj ovog istraživanja je istražiti kako se koncentracija alge, efikasnost usvajanja hranljivih materija i elementarni sastav alge Desmodesmus sp. menja u odnosu na različite vrste džibre (sirova i digestivna). Biomasa alge Desmodesmus sp. je gajena i skupljena u laboratorijskim razmerama. Dobijene su koncentracije od 0,5 g/L i 0,3 g/L za Desmodesmus sp. gajenim u sirovoj i digestivnoj džibri, respektivno. Pri ovim koncentracijama, efikasnosti usvajanja ukupnog ugljenika i azota iz džibre su: $39,78 \%$ i 5,58\% za sirovu; 20,83\% i $5,43 \%$ za digestivnu džibru, respektivno. Alga Desmodesmus sp. korišćena u ovom istraživanju sadržala je veliki udeo ugljenika i kiseonika, slično drugim algalnim vrstama. Kalcijum, fosfor i sumpor bila su tri najviše zastupljena neorganska elementa. Obe biomase su imale nizak sadržaj kalijuma i nisu sadržale hlor. Sadržaj fosfora u obe biomase je bio u opsegu $6,03 \%-6,84 \%$, što bi moglo klasifikovati ove biomase kao korisne biljne hranljive materijale.
Ključne reči: Džibra šećerne trske, Desmodesmus sp., biomasa, elementarni sastav. 